\title{
Chromosome numbers of invasive and potentially invasive species in the flora of the Republic of Altai. III
}

\author{
E. Yu. Zykova*, T. V. An’kova, M. N. Lomonosova \\ Federal State Institution of Science Central Siberian Botanical Garden of Siberian Branch of RAS, Zolotodolinskaya str., 101, \\ Novosibirsk,630090, Russian Federation.*E-mail: elena.yu.zykova@gmail.com \\ * Corresponding author
}

Keywords: Apiaceae, Asteraceae, Brassicaceae, Caryophyllaceae, Fabaceae, karyological study, Lamiaceae, Poaceae, species distribution, Urticaceae.

Summary. Chromosome numbers $(2 n)$ in 10 invasive plant species from the families Apiaceae, Asteraceae, Brassicaceae, Caryophyllaceae, Fabaceae, Lamiaceae, Poaceae and Urticaceae are reported on the samples collected in the Republic of Altai. Among them, chromosome complements were first examined in Asian part of Russia for Lapsana communis $(2 n=14)$. Saponaria officinalis $(2 n=28)$ and Lotus corniculatus $(2 n=24)$ were studied first from Siberia. Six species: Conium maculatum $(2 n=22)$, Bunias orientalis $(2 n=14)$, Vicia hirsuta $(2 n=14)$, Leonurus quinquelobatus $(2 n=18)$, Digitaria ischaemum $(2 n=36)$ and Setaria pumila $(2 n=36)$, were studied first from the Republic of Altai. The most studied species are diploids. General distribution and the history of floristic findings of these species in the Republic of Altai are given. Previously published data on chromosome numbers based on the material from Russia are cited.

\section{Числа хромосом инвазивных и потенциально инвазивных видов во флоре Республики Алтай: сообщение 3}

\author{
Е. Ю. Зыкова, Т. В. Анькова, М. Н. Ломоносова
}

Федеральное государственное бюджетное учреждение науки «Центральный сибирский ботанический сад» Сибирского отделения РАН, ул. Золотодолинская, 101, г. Новосибирск, 630090, Россия. E-mail: elena.yu.zykova@gmail.com

Ключевые слова: кариологическое изучение, расселение видов, Apiaceae, Asteraceae, Brassicaceae, Caryophyllaceae, Fabaceae, Lamiaceae, Poaceae, Urticaceae.

Аннотация. Приводятся данные о числах хромосом (2n) для 10 инвазивных видов из семейств Арiaceae, Asteraceae, Brassicaceae, Caryophyllaceae, Fabaceae, Lamiaceae, Poaceae, Urticaceae, полученные на материале из Республики Алтай. Впервые для Азиатской части России определено число хромосом у Lapsana communis $(2 n=14)$, впервые для Сибири - у Saponaria officinalis $(2 n=28)$ и Lotus corniculatus $(2 n=24)$, впервые для Республики Алтай - у Conium maculatum $(2 n=22)$, Bunias orientalis $(2 n=14)$, Vicia hirsuta $(2 n=14)$, Leonurus quinquelobatus $(2 n=18)$, Digitaria ischaemum $(2 n=36)$, Setaria pumila $(2 n=36)$. Большинство изученных видов являются диплоидами. Для всех исследованных видов приводятся сведения по общему распространению, истории флористических находок и расселению на территории Республики Алтай, а также литературные данные по числам хромосом, опубликованные на материале с территории России. 
We continue the karyological study of invasive and potentially invasive species in the flora of Southern Siberia on the example of the Republic of Altai (Lomonosova et al., 2018; Zykova et al., 2018), one of the most visited regions of Siberia. The growth of tourist flow followed by the increase of disturbed natural habitats contribute to introduction of a significant number of diasporas of alien plants. It is important to trace whether invasive species form new cytological races under new conditions. This paper provides an information about 10 species that are most active in the republic, seven of which are included in the list of invasive or potentially invasive species of Siberia (Ebel et al., 2014).

The information on the history of floristic studies of examined species in the territory of the Republic of Altai is provided here. For all species, the references on chromosome numbers revealed from the samples collected in Russia are given as well, while relevant information in the international databases "The Chromosome Counts Database" (Rice et al., 2015) and "Index to Plant Chromosome Numbers" (Goldblatt, Johnson, 1979+) is reflected incompletely.

The chromosome numbers were determined by direct count in metaphase on squash preparations of root meristem. Seeds were germinated at $25{ }^{\circ} \mathrm{C}$ (day) and $16{ }^{\circ} \mathrm{C}$ (night) on sterile sand. The root tips were pretreated for two hours with $0.2 \%$ colchicine water solution, fixed in $3: 1$ absolute ethanol-glacial acetic acid and stained with $1 \%$ acetic hematoxylin. Metaphase plates were observed under 100× magnification by the Axioscope 40 (Karl Zeiss, Axio $\mathrm{Lab}$ ) and photographed by the AxiCam MRc 5 digital camera. The herbarium specimens (vouchers) are deposited in the Herbarium of the Central Siberian Botanical Garden SB RAS (NS). For species marked with an asterisk $(*)$, the chromosome number was determined in Siberia for the first time.

\section{APIACEAE}

Conium maculatum L., $2 n=22$

"Russian Federation, the Republic of Altai, Mayma district, vicinity of Rybalka village, wasteland at a construction site, $51^{\circ} 55^{\prime} \mathrm{N}, 85^{\circ} 51^{\prime} \mathrm{E}$. 2 VIII 2015. E. Zykova", Z429-3315 (Fig. 1A); "Russian Federation, the Republic of Altai, Choya district, vicinity of Sugul village, gravel roadside, $52^{\circ} 03^{\prime} \mathrm{N}, 86^{\circ} 15^{\prime}$ E. 07 VIII 2015. E. Zykova", Z4273615 .

Biennial. Eurasian species growing in most regions of Siberia (Ebel et al., 2014). The first records in the republic date back to 1980s (Rostovtseva, 1976; Nikiforov, 1989). At present, it is common in northern regions though registers in the central parts of the republic (Zykova, 2015). Main habitats are courtyards, along the banks of water bodies, vegetable gardens, landfills and deposits.

The same chromosome number has been previously reported for the Republic of Crimea (Rostovtseva, 1982) and Novosibirsk Region (Krasnikov, Lomonosova, 1990; Krivenko et al., 2013). Ploidy set $n=11$ was determined from the Turochak District of the Republic of Altai (Rostovtseva, 1976).

Diploid $(2 x), x=11$.

\section{ASTERACEAE}

*Lapsana communis L., $2 n=14$

"Russian Federation, the Republic of Altai, Gorno-Altaysk city, Shosseynaya street, wasteland, $51^{\circ} 58^{\prime} \mathrm{N}, 85^{\circ} 55^{\prime}$ E. 22 VIII 2017. E. Zykova”, Z6116717 (Fig. 1B).

Annual. Euro-Mediterranean species with a Holarctic secondary range. Known in most regions of Southern Siberia (Ebel et al., 2014). Until recently, only three localities were known in the territory of the republic: Ust-Kan village (Krylov, 1904), the vicinity of Manzherok village and the city of Gorno-Altaysk (Zykova, 2012). In recent years, it has been very actively settling in the city of Gorno-Altaysk, abundant along the banks of the Mayma River (Zykova et al., 2019).

The number of chromosomes was first determined for the Asian part of Russia. The same chromosome complement has been published earlier from the Republic of Karelia and the Leningrad Region (Probatova et al., 2009), the Republic of North Ossetia-Alania (Probatova, Seledets, 2008), and Krasnodar Territory (Probatova et al., 2013a).

Diploid $(2 x), x=7$.

\section{BRASSICACEAE \\ Bunias orientalis L., $2 n=14$}

"Russian Federation, the Republic of Altai, Gorno-Altaysk city, surroundings of the stadium Spartak, pebble banks of the Mayma river, $51^{\circ} 954939^{\prime} \mathrm{N}, 8^{\circ} 952793^{\prime} \mathrm{E} .29$ VIII 2018. E. Zykova", Z694-3018 (Fig. 1C).

Biennial or perennial herb. Eurasian species, widely distributed over Siberian regions (Ebel et al., 2014). Since the mid-20th century, it has been observed in the territory of the republic as weedy in cultivated fields of Northern Altai (Kuminova, 1960). It is possible that the species could penetrate the territory of the republic at a much earlier period. Thus, the fruits of Bunias orientalis were identified during the study of paleocarpological material of a 
burial mound of the Chinet II burial ground (Altai Territory) dating from the 4th century to the 3rd century BC (Dashkovskiy et al., 2014). However, despite the proximity of the territories, we cannot reliably confirm the species invasion in the same period into this territory. In the Republic of Altai, it is currently one of the most widespread species, common in the northern regions and penetrating to the central ones (Zykova, 2015). It was also found in the southeast (Ebel, 1997).

This chromosome number confirms earlier counts from Irkutsk Region (Chepinoga, 2014, and references therein) and Primorye Territory (Probatova, 2014, and references therein). The same number is typical for most definitions (Goldblatt, Johnson, 1979+; Rice et al., 2015). Indications of $2 n=28$ (Lövkvist, Hultgård, 1999) and $2 n=42$ (Jaretzky, 1928) were later questioned (Greilhuber, Obermayer, 1999).

Diploid $(2 x), x=7$.

\section{CARYOPHYLLACEAE}

*Saponaria officinalis L. $2 n=\mathbf{2 8}$

"Russian Federation, the Republic of Altai, Gorno-Altaysk city, Sportivnyy lane, wasteland, $51^{\circ} 58^{\prime} \mathrm{N}, 85^{\circ} 55^{\prime}$ E. 18 VIII 2017. E. Zykova", Z3256217 (Fig. 1D).

Perennial herb. Species is native in Europe and West Asia, spreads over the Holarctic including Siberia (Ebel et al., 2014). In the Republic of Altai, this species withdrawal from culture was recorded in the 2010s. (Shaulo et al., 2010). Presently, it is common in landfills, wastelands, often forming thickets in Gorno-Altaysk and the Mayma District. Later, it was found in the Turochak and Ulagan Districts (Zolotukhin, 2012; Zykova, 2015).

The chromosome number is determined first on Siberian material. The same data were obtained from Primorye Territory (Probatova, 2014 and references therein).

Diploid $(2 x), x=14$.

\section{FABACEAE}

*Lotus corniculatus L. S. 1., $2 n=\mathbf{2 4}$

"Russian Federation, the Republic of Altai, Mayma District, vicinity of Kysyl-Ozek village, quarry at a closed landfill, $51^{\circ} 58^{\prime} \mathrm{N}, 85^{\circ} 55^{\prime} \mathrm{E} .15$ VIII 2018. E. Zykova", Z677-2418a; "Russian Federation, the Republic of Altai, Gorno-Altaysk city, surroundings of the stadium Spartak, pebble banks of the Mayma river, 51 $954939^{\prime} \mathrm{N}, 85^{\circ} 952793^{\prime}$ E. 29 VIII 2018. E. Zykova", Z679-3018 (Fig. 1E).

Perennial herb. European-Caucasian-Central Asian species. Over the past two decades, it has pen- etrated into Western Siberia often acting as a dominant (Ebel et al., 2014). Outside of culture, it was first recorded in Mayma District in 1997 (Zykova, 2014). At present, it is active in this district and in Gorno-Altaysk, forms extended thickets along the banks, on wastelands, along roads. Recently discovered in Choya District (Zykova et al., 2019).

This is the first chromosome count in Siberian population, which agrees with the data reported for Primorye Territory (Probatova, 2014 and references therein), the Republic of North Ossetia - Alania (Efimov, 1998), European part of Russia (Kramina, 1999).

Tetraploid (4x), $x=6$.

Vicia hirsuta (L.) Gray, 2n = 14

"Russian Federation, the Republic of Altai, Mayma District, vicinity of Mayma village, along country roads, $52^{\circ} 02^{\prime} \mathrm{N}, 85^{\circ} 54^{\prime} \mathrm{E} .12$ VIII 2017 . E. Zykova", Z385-5017 (Fig. 1F).

Annual. The European-Mediterranean species, which has spread throughout the globe including Siberia (Ebel et al., 2014). First record in the Republic of Altai was made in 2010 (Zykova, 2012). Now it is common in Mayma District and in the city of Gorno-Altaysk, penetrating Chemal District (Zykova, 2015). The plants grow along the roads and embankments, in cultivated fields and deposits, invading meadows as well.

This chromosome number confirms earlier counts from Irkutsk Region (Chepinoga, 2014, and references therein), Primorye Territory (Probatova, 2014, and references therein), Khabarovsk Territory (Probatova et al., 2011), and the Republic of Ingushetia (Efimov, 1987).

Diploid $(2 x), x=7$.

\section{LAMIACEAE}

Leonurus quinquelobatus Gilib., L. cardiaca auct. non L.: Krylov, 1937, Flora of Western Siberia, 9: $2357, \mathbf{2 n}=\mathbf{1 8}$

"Russian Federation, the Republic of Altai, Gorno-Altaysk city, Kosmonavtov street, by the fences, along the roads, $51^{\circ} 58^{\prime} \mathrm{N}, 85^{\circ} 55^{\prime} \mathrm{E}$. 25 VIII 2017. E. Zykova", Z397-7017; "Altai Territory, Sovetskoye District, the village of Shulgin Log, along the streets, along the road, $52^{\circ} 11^{\prime} \mathrm{N}, 85^{\circ} 50^{\prime} \mathrm{E}$. 01 VIII 2015. E. Zykova", Z527-3215 (Fig. 1G).

Perennial herb. The European-West Asian species penetrated into Siberia and the Far East (Ebel et al., 2014). The first locality in the republic was mentioned for the village of Anos of Chemal District (Krylov, 1937), by the end of the 20th century it was also known in the village of Rybalka in Mayma 
District (Krestovskaya, 1997) and in the village of Uymen of Choya District (Silantieva, 1994). Now it is one of the most widespread species in disturbed habitats in the northern regions of the republic.

This chromosome number confirms earlier counts from Novosibirsk Region (Krasnikov, 1991), Krasnoyarsk Territory (Stepanov, Muratova, 1995), and Sakhalin Region (Probatova et al., 2017).

Diploid $(2 x), x=9$.

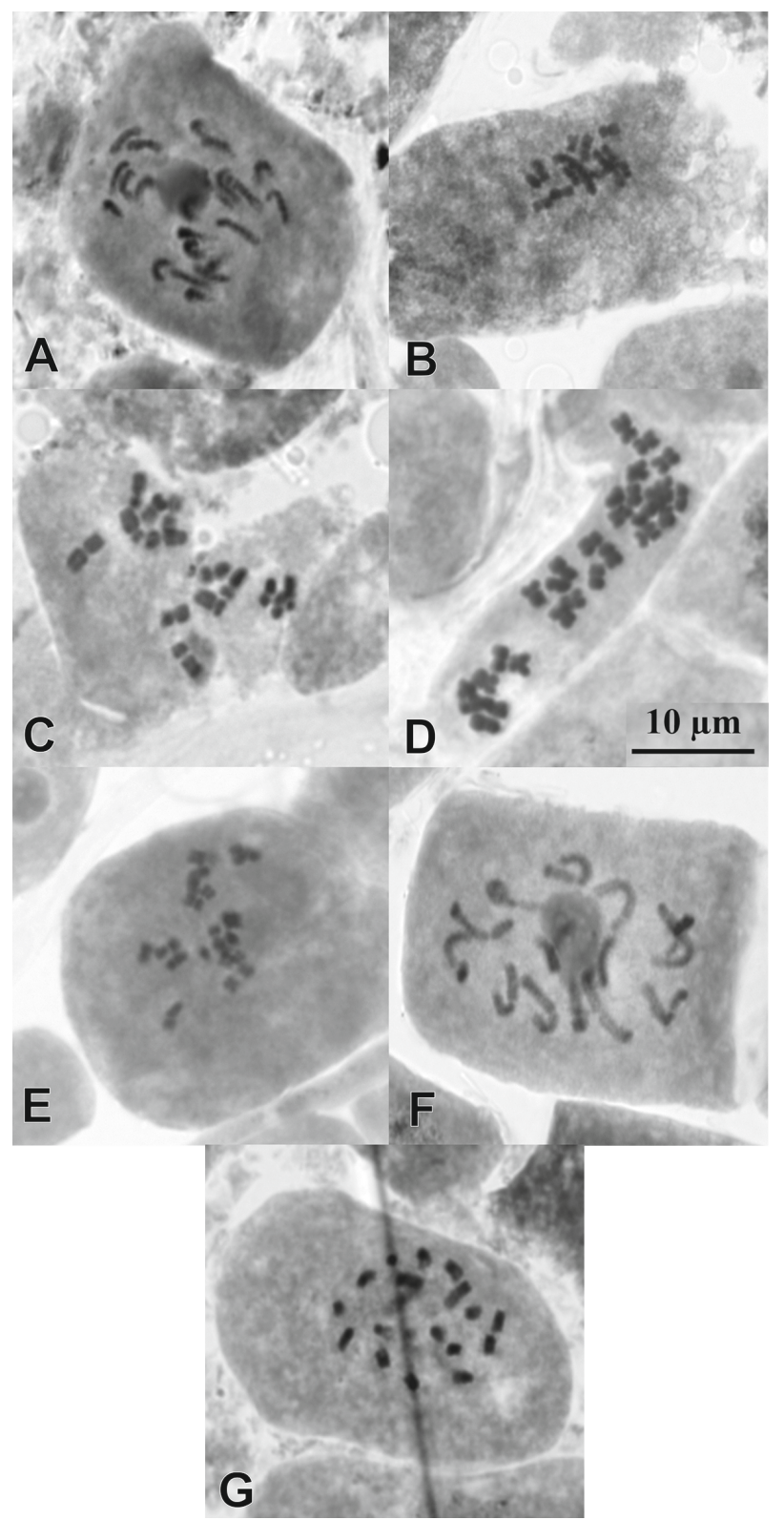

Fig. 1. Mitotic metaphase and late prophase of some invasive species: A - Conium maculatum, $2 n=22$; $\mathbf{B}-$ Lapsana communis, $2 n=14 ; \mathbf{C}-$ Bunias orientalis, $2 n=$ 14; D - Saponaria officinalis, $2 n=28 ; \mathbf{E}$ - Lotus corniculatus, $2 n=24 ; \mathbf{F}-$ Vicia hirsuta, $2 n=14 ; \mathbf{G}-$ Leonurus quinquelobatus, $2 n=18$. Scale $=10 \mu \mathrm{m}$.

\section{POACEAE}

Digitaria ischaemum (Schreb.) Muehl., 2n = 36

"Russian Federation, the Republic of Altai, Turochak District, Iogach village, stadium, $51^{\circ} 46^{\prime} \mathrm{N}$, $87^{\circ} 15^{\prime}$ E. 15 VIII 2017. E. Zykova”, Z456-5517.

Annual. As alien, this Palaearctic species is almost cosmopolitan though rare in Siberia. In the Altai Republic, the first locations were recorded at the beginning of the 20th century in Mayma and Chemal Districts (Krylov, 1928). Now it is found in GornoAltaysk, Onguday and Turochak Districts (Zykova, 2015) occuring on gravel substrates: roadsides, stadiums, and on sites trampled and overgrazed by cattle. According to our observations, it is a potentially invasive species in the Republic of Altai.

This chromosome number confirms earlier counts from the Primorye Territory (Probatova, 2014, and references therein), Volgograd Region (Probatova et al., 2008), the Republic of Buryatia (Probatova et al., 2016). $2 n=18$ was determined from Khabarovsk Territory (Probatova et al., 1996).

Tetraploid $(4 x), x=9$.

Setaria pumila (Poir.) Roem. et Schult., $2 n=36$

"Russian Federation, the Republic of Altai, Gorno-Altaysk city, Naberezhnyy lane, weedy on flowerbeds and by fences, $51^{\circ} 58^{\prime} \mathrm{N}, 85^{\circ} 55^{\prime} \mathrm{E} .11$ VIII 2017. E. Zykova", Z495-4717.

Annual.A species with a wide Eurasian-American range. In the territory of the Republic of Altai, isolated locations were recorded at the beginning of the 20th century in Chemal District (Krylov, 1928). Now it is an ubiquitous anthropophilic species in northern and central districts of the republic.

This chromosome number confirms earlier counts from Irkutsk Region (Chepinoga, 2014, and references therein), the Republic of Buryatia (Probatova et al., 2015), Primorye Territory (Probatova, 2014, and references therein), Krasnodar Territory (Probatova et al., 2009, 2014b, 2015), Volgograd Region (Probatova et al., 2013b), and Amur Region (Probatova et al., 2014a). $2 n=18$ was determined from Amur Region (Probatova et al., 2013b) as well.

Tetraploid $(4 x), x=9$.

\section{URTICACEAE}

\section{Urtica urens L., $2 n=24$}

"Russian Federation, the Republic of Altai, Mayma District, Podgornoye village, wasteland, $52^{\circ} 01^{\prime} \mathrm{N}, 85^{\circ} 53^{\prime}$ E. 24 VI 2017. E. Zykova”, Z3611417. 
Annual. European species with a cosmopolitan secondary range. The first locations in Altai were recorded at the beginning of the 20th century (Krylov, 1930). Currently distributed in northern, western and central regions of the republic (Zykova, 2015) growing in courtyards, cultivated fields, preferably on loose, moist soils.

We determined earlier the same chromosome number from one of the central regions (An'kova, Zykova, 2018). These are the first data from the northern region of the Republic of Altai. The same chromosome number is indicated for most parts of Europe (Rice et al., 2015). Other data were obtaimed from the material from Russia: $2 n=24-25$ for Primorye Territory and $2 n=26$ for Murmansk Region (Geltman, 1984).

Diploid $(2 x), x=12$.

\section{Conclusion}

Chromosome numbers of 39 invasive species distributed in the Republic of Altai were examined. The data for 10 species is represented in this study. Among them, chromosome complements were examined on the material from the Asian part of Russia for Lapsana communis for the first time. Saponaria officinalis and Lotus corniculatus were studied first on the material from Siberia. Chromosome numbers for Conium maculatum, Bunias orientalis, Vicia hirsuta, Leonurus quinquelobatus, Digitaria ischaemum and Setaria pumila were first investigated in the Republic of Altai. The most of the studied invasive species are diploids. Polyploids Lotus corniculatus and Digitaria ischaemum have begun to exhibit invasive properties during the last 5 years. The polyploid Setaria pumila, apparently an archaeophyte, has spread very widely and is one of the most common species in human-disturbed habitats.

\section{Acknowledgements}

The study was carried out within the framework of the Scientific Program № AAAA-A17-117012610055-3 of the Central Siberian Botanical Garden SB RAS.

\section{REFERENCES / ЛИТЕРАТУРА}

An'kova T. V., Zykova E. Yu. 2018. IAPT/IOPB chromosome data 27 in Marhold (ed.). Taxon 67(5): 1041-1042. DOI: $10.12705 / 675$

Chepinoga V. V. 2014. Chromosome numbers of plant species from Baikal Siberia. Novosibirsk: Nauka. 419 pp. [In Russian] (Чепинога В. В. Хромосомные числа растений флоры Байкальской Сибири. Новосибирск: Наука, 2014. 419 c.).

Dashkovskiy P. K., Silantyeva M. M., Speranskaya N. Yu., Sinitsyna T. A. 2014. Issledovaniye rastitelnykh ostatkov iz kurgana 19 mogilnika Chineta II (Severo-Zapadnyy Altay) [Investigation of plant residues from the mound 19 of burial ground Chinet II (North-Western Altai)]. Novosibirsk State University Journal. Series: History, Philology 13, 7: 29-35. [In Russian] (Дашковский П. К., Силантьева М. М., Сперанская Н. Ю., Синицына Т. А. Исследование растительных остатков из кургана 19 могильника Чинета II (Северо-Западный Алтай) // Вестн. Новосиб. гос. ун-та. Серия: История, филология, 2014. Т. 13, вып. 7. С. 29-35).

Ebel A. L. 1997. The new data on the distribution of the Brassicaceae in the South of Siberia. Bot. Zhurn. (Moscow \& St. Petersburg) 82(12): 101-104. [In Russian] (Эбель А. Л. Новые данные о распространении крестоцветных (Brassicaceae) на юге Сибири // Бот. журн., 1997. Т. 82, № 12. С. 101-104).

Ebel A. L., Strelnikova T. O., Kupriyanov A. N., Anenkhonov O. A., Ankipovich E. C., Antipova E. M., Verkhozina A. V., Efremov A. N., Zykova E. Yu., Mikhaylova S. I., Plikina N. V., Ryabovol S. V., Silantyeva M. M., Stepanov N. V., Terekhina T. A., Chernova O. D., Shaulo D. N. 2014. Invasive and potential invasive species of Siberia. Byull. Glavn. bot. sada (Moscow) [Bulletin of Main Botanical Garden] 1(200): 52-61. [In Russian] (Эбель А. Л., Стрельникова Т. О., Куприянов А. Н., Аненхонов О. А., Анкипович Е. С., Антипова Е. М., Верхозина А. В., Ефремов А. Н., Зыкова Е. Ю., Михайлова С. И., Пликина Н. В., Рябовол С. В., Силантьева М. М., Степанов Н. В., Терехина Т. А., Чернова О. Д., Шауло Д. Н. Инвазионные и потенциально инвазионные виды Сибири // Бюл. Глав. ботан. сада, 2014. № 1 (вып. 200). С. 52-61).

Efimov K. F. 1987. Chromosome numbers in some members of the Fabaceae from central Caucasus. Bot. Zhurn. (Moscow \& St. Petersburg) 72(6): 845. [In Russian] (Ефимов К. Ф. Числа хромосом некоторых видов семейства Fabaceae Центрального Кавказа // Бот. журн., 1987. Т. 72, № 6. С. 845).

Efimov K. F. 1998. Chromosome numbers in some species of the families Asteraceae, Campanulaceae, Fabaceae from central Caucasus. Bot. Zhurn. (Moscow \& St. Petersburg) 83(8): 131-132. [In Russian] (Ефимов К. Ф. Числа хромосом некоторых видов семейств Asteraceae, Campanulaceae, Fabaceae Центрального Кавказа // Бот. журн., 1998. Т. 83, № 8. С. 131-132). 
Geltman D. V. 1984. Cytotaxonomical studies of the species of the genus Urtica (Urticaceae) in the Flora of the USSR. Bot. Zhurn. (Moscow \& St. Petersburg) 69(11): 1524-1530. [In Russian] (Гельтман Д. В. Цитотаксономическое изучение видов рода Urtica (Urticaceae) флоры СССР // Бот. журн., 1984. Т. 69, № 11. С. 1524-1530).

Goldblatt P., Johnson D. E. (eds). 1979+. Index to plant chromosome numbers (IPCN). URL: http://www.tropicos.org/Project/IPCN (Accessed 31 May 2018).

Greilhuber J., Obermayer R. 1999. Cryptopolyploidy in Bunias (Brassicaceae) revisited - A flow-cytometric and densitometric study. Plant Systematics and Evolution 218, 1-2: 1-4. URL: https://link.springer.com/article/10.1007/ BF01087028

Jaretzky R. 1928. Untersuchungen über Chromosomen und Phylogenie bei einigen Cruciferen. Jahrbücher für Wissenschaftliche Botanik 68: 1-45.

Kramina T. E. 1999. A contribution to the taxonomic revision of the Lotus corniculatus complex (Leguminosae, Loteae) in the European part of the former USSR. Systematics and Geography of Plants 68(1/2): 265-279. DOI: $10.2307 / 3668607$

Krasnikov A. A. 1991. Chromosome numbers in some species of vascular plants from Novosibirsk region. Bot. Zhurn. (Moscow \& Leningrad) 76(3): 476-479. [In Russian] (Красников А. А. Числа хромосом некоторых видов сосудистых растений Новосибирской области // Бот. журн., 1991. Т. 76, № 3. С. 476-479).

Krasnikov A. A., Lomonosova M. N. 1990. Chromosome numbers in representatives of some families of vascular plants in the flora of the Novosibirsk region. I. Bot. Zhurn. (Moscow \& Leningrad) 75(1): 116-118. [In Russian] (Красников А. А., Ломоносова М. Н. Хромосомные числа представителей из некоторых семейств флоры Новосибирской области, 1 // Бот. журн., 1990. Т. 75, № 1. С. 116-118).

Krestovskaya T. V. 1997. Leonurus L. In: Flora Sibiri [Flora of Siberia]. Vol. 11. Novosibirsk: Nauka. Pp. 192195. [In Russian] (Крестовская T. В. Leonurus L. - Пустырник // Флора Сибири. Т. 11. Новосибирск: Наука, 1997. C. 192-195).

Krivenko D. A., Kotseruba V. V., Kazanovsky S. G., Verkhozina A. V., Chernova O. D. 2013. IAPT/IOPB chromosome data 16 in Marhold (ed). Taxon 62 (6): 1356-1357. DOI: 10.12705/626.41

Krylov P. N. 1904. Lapsana L. In: Flora Altaya i Tomskoy gubernii [Flora of Altai and Tomsk province]. Vol. 3. Tomsk. P. 725. [In Russian] (Крылюв П. Н. Lapsana L. // Флора Алтая и Томской губернии. Т. 3. Томск, 1904. С. 725).

Krylov P. N. 1928. Panicum L., Setaria P. B. In: Flora Zapadnoy Sibiri [Flora of Western Siberia]. Vol. 2. Tomsk: Izdatelstvo Tomskogo Universiteta. Pp. 149-151, 152-154. [In Russian] (Крылов П. Н. Panicum L., Setaria P. B. // Флора Западной Сибири. Т. 2. Томск: Изд-во ТГУ, 1928. С. 149-151, 152-154).

Krylov P. N. 1930. Urtica L. In: Flora Zapadnoy Sibiri [Flora of Western Siberia]. Vol. 4. Tomsk: Izdatelstvo Tomskogo Universiteta. Pp. 807-810. [In Russian] (Крылов П. Н. Urtica L. // Флора Западной Сибири. Т. 4. Томск: Изд-во ТГУ, 1930. С. 807-810).

Krylov P. N. 1937. Leonurus L. In: Flora Zapadnoy Sibiri [Flora of Western Siberia]. Vol. 9. Tomsk: Izdatelstvo Tomskogo Universiteta. Pp. 2353-2360. [In Russian] (Крылюв П. Н. Lеопиrus L. Флора Западной Сибири. Т. 2. Томск: Изд-во ТГУ, 1937. С. 2353-2360).

Kuminova A. V. 1960. Rastitelnyy pokrov Altaya [Plant cover of Altai]. Novosibirsk. 450 pp. [In Russian] (Kyмuнова A. В. Растительный покров Алтая. Новосибирск, 1960. 450 с.).

Lomonosova M. N., Zykova E. Yu., An'kova T. V. 2018. Chromosome numbers of invasive species of the Altai Republic flora. II. Turczaninowia 21, 4: 63-72. DOI: 10.14258/turczaninowia.21.4.7

Lövkvist B., Hultgård U. M. 1999. Chromosome numbers in south Swedish vascular plants. Opera Bot. 137: 1-42.

Nikiforov Yu. V. 1989. Zavetnye travy Altaya [Treasured herbs of Altai]. Barnaul, 208 pp. [In Russian]. (Никифоров Ю. В. Заветные травы Алтая. Барнаул, 1989. 208 с.).

Probatova N. S. 2014. Chromosome numbers in vascular plants of the Primorskii Territory (Russian Far East). Vladivostok: Dalnauka. 343 pp. [In Russian] (Пробатова Н. С. Хромосомные числа сосудистых растений Приморского края. Владивосток: Дальнаука, 2014. 343 с.).

Probatova N. S., Kazanovsky S. G., Rudyka E. G., Barkalov V. Yu., Seledets V. P., Nechaev V. A. 2011. IAPT/ IOPB chromosome data 12 in Marhold (ed.). Taxon 60(6): 1790-1794.

Probatova N. S., Kazanovskiy S. G., Rudyka E. G., Seledets V. P., Ovchinnikova S. V. 2013a. IAPT / IOPB chromosome data 16 in Marhold (ed.) Taxon 62(6): 1358-1359. DOI: 10.12705/626.41

Probatova N. S., Krivenko D. A., Barkalov V. Yu. 2017. Further chromosome studies on the flora of Sakhalin and the Kurils, with additions from adjacent regions of the Russian Far East. Botanica Pacifica 6(2): 69-75. DOI: 10.17581/bp.2017.06209

Probatova N. S., Rudyka E. G., Krivenko D. A., Verkhozina A. V., Nechaev V. A. 2015. IAPT/IOPB chromosome data 20 in Marhold (ed.). Taxon 64(6): 1349-1350. DOI: 10.12705/646.42

Probatova N. S., Rudyka E. G., Seledets V. P., Motorykina T. N. 2014a. Chromosome Numbers in Vascular Plants from the Russian Far East: Amurskaya Oblast', Khabarovskii Krai, Primorskii Krai. Botanica Pacifica 3(2): $129-134$. DOI: $10.17581 /$ bp.2014.03207 
Probatova N. S., Rudyka E. G., Seledets V. P., Nechaev V. A. 2008. IAPT/IOPB chromosome data 6 in Marhold (ed.). Taxon 57(4): 1268-1271. URL: http://www.jstor.org/stable/27756778

Probatova N. S., Rudyka E. G., Sokolovskaya A. P. 1996. Chromosome numbers in synanthropic plants from the Russian Far East. Bot. Zhurn. (Moscow \& St. Petersburg) 81(5): 98-101. [In Russian] (Пробатова Н. С., Рудыка Э. $\boldsymbol{\Gamma}$., Соколовская A. П. Числа хромосом синантропных видов растений с Дальнего Востока России // Бот. журн., 1996. Т. 81, № 5. C. 98-101).

Probatova N. S., Seledets V. P. 2008. IAPT/IOPB chromosome data 5 in Marhold (ed.). Taxon 57(2): 555-558. URL: http://www.iapt-taxon.org/files/iopb/IAPT_IOPB_Chr_data5.pdf

Probatova N. S., Seledets V. P., Chernyagina O. A. 2016. Chromosome numbers in some species of Poaceae from Russia: further studies. Botanica Pacifica 5(2): 59-65. DOI: 10.17581/bp.2016.05201

Probatova N. S., Seledets V. P., Rudyka E. G. 2014b. IAPT/IOPB chromosome data 18 in Marhold (ed.). Taxon 63(6): 1391-1393.

Probatova N. S., Seledets V. P., Rudyka E. G., Gnutikov A. A., Kozhevnikova Z. V., Barkalov V. V. 2009. IAPT/ IOPB chromosome data 8 in Marhold (ed.). Taxon 58(4): 1284-1288.

Probatova N. S., Verkhozina A. V., Rudyka E. G., Krivenko D. A. 2013b. IAPT / IOPB chromosome data 16 in Marhold (ed.) Taxon 62(6): 1359-1360. DOI: 10.12705/626.41

Rice A., Glick L., Abadi S., Einhorn M., Kopelman N., Salman-Minkov A., Mayzel J., Chay O., Mayrose I. 2015. The Chromosome Counts Database (CCDB) - a community resource of plant chromosome numbers. New Phytol. 206(1): 19-25. URL: http://ccdb.tau.ac.il (Accessed 31 May 2018).

Rostovtseva T. S. 1976. Chromosome numbers of some species of the family Apiaceae in South Siberia. Bot. Zhurn. (Moscow \& Leningrad) 61(1): 93-99. [In Russian] (Ростовцева T. С. Числа хромосом ряда видов семейства Аріасеае на юге Сибири // Бот. журн., 1976. Т. 61, № 1. С. 93-99).

Rostovtseva T. S. 1982. Chromosome numbers of some species of the family Apiaceae. III. Bot. Zhurn. (Moscow \& Leningrad) 67(2): 206-210. [In Russian] (Ростовцева T. C. Числа хромосом некоторых видов семейства Аріаceae - 3 // Бот. журн., 1982. Т. 67, № 2. C. 206-210).

Shaulo D. N., Zykova E. Yu., Drachev N. S., Kuzmin I. V., Doronkin V. M. 2010. Floristic findings in West and Middle Siberia. Turczaninowia 13, 3: 77-91. [In Russian] (Шауло Д. Н., Зыкова Е. Ю., Драчев Н. С., Кузьмин И. B., Доронькин В. М. Флористические находки в Западной и Средней Сибири // Turczaninowia, 2010. Т. 13, № 3. С. 77-91).

Silantieva M. M. 1994. Flora of the Sumultin Range (Northern Altai): diss. ... cand. biol. sciences [Flora Sumultinskogo khrebta (Severnyy Altay): diss. ... kand. biol. nauk.]. Novosibirsk. 283 pp. [In Russian] (Силантьева M. M. Флора Сумультинского хребта (Северный Алтай): дисс. ... канд. биол. наук. Новосибирск, 1994. 283 с.).

Stepanov N. V., Muratova E. N. 1995. Chromosome numbers of some taxa of higher plants of Krasnoyarsk territory. Bot. Zhurn. (Moscow \& Leningrad) 80(6): 114-116. [In Russian] (Сmenaнoв Н. В., Муратова Е. Н. Хромосомные числа некоторых таксонов высших растений Красноярского края // Бот. журн., 1995. Т. 80, № 6. С. 114-116).

Zolotukhin N. I. 2012. Floristic records in Altai Republic. Byulleten MOIP. Otdel biologicheskiy [Bulletin of Moscow Society of Naturalists. Biological series] 117, 3: 77-80. [In Russian] (Золотухин Н. И. Флористические находки в Республике Алтай // Бюл. МОИП. Отд. биол., 2012. Т. 117, вып. 3. С. 77-80).

Zykova E. Yu. 2012. New findings of adventive species in Altai. Rastitelnyy mir Aziatskoy Rossii [Plant Life of Asian Russia] 1: 50-54. [In Russian] (Зыкова E. Ю. Новые находки адвентивных видов на Алтае // Растительный мир Азиатской России, 2012. № 1(9). С. 50-54).

Zykova E. Yu. 2014. New records of alien species in the Altai Republic flora. Byulleten MOIP. Otdel biologicheskiy [Bulletin of Moscow Society of Naturalists. Biological series] 119, 1: 80-81. [In Russian] (3ыкова Е. Ю. Новые находки адвентивных видов во флоре Республики Алтай // Бюл. МОИП. Отд. биол., 2014. Т. 119, вып. 1. С. 80-81). URL: http://herba.msu.ru/russian/journals/bmsn/archive/moip_2014_119_1.pdf

Zykova E. Yu. 2015. Alien flora of the Altai Republic. Rastitelnyy mir Aziatskoy Rossii [Plant Life of Asian Russia] 3(19): 72-87. [In Russian] (Зыкова E. Ю. Адвентивная флора Республики Алтай // Растительный мир Азиатской России, 2015. № 3(19). С. 72-87). URL: http://www.izdatgeo.ru/pdf/rast/2015-3/72.pdf

Zykova E. Yu., Ebel A. L., Ebel T. V., Sheremetova S. A. 2019. New findings of alien plants in the Republic of Altai. Turczaninowia 22, 1: 143-153. [In Russian] (Зыкова Е. Ю., Эбель А. Л., Эбель Т. В., Шереметова С. А. Новые находки адвентивных видов растений в Республике Алтай // Turczaninowia, 2019. Т. 22, № 1. С. 143-153). DOI: 10.14258/turczaninowia.22.1.11

Zykova E. Yu., Lomonosova M. N., An'kova T. V. 2018. Chromosome numbers of invasive species of the Altai Republic flora: post 1. Turczaninowia 21, 1: 41-51. [In Russian] (Зыкова Е. Ю., Ломоносова М. Н., Анькова Т. В. Числа хромосом инвазионных видов во флоре Республики Алтай: сообщение 1 // Turczaninowia, 2018. Т. 21, № 1. C. 41-51). DOI: 10.14258/turczaninowia.21.1. 